\title{
Moving Genetics into Medicine
}

My interest in science blossomed in, of all places, law school. It was really an epiphany. I became convinced pretty quickly that I did not want to be a straight corporate attorney. I began searching for a creative way to put my training in law together with some other field.

One night in 1971 I was walking across the Columbia campus in New York and I said, "Genetics is going to be really big in my lifetime." So here I am at law school trying to find a path into genetics. I wrote to a very famous professor of genetics at my alma mater, Cornell University in Ithaca, NY. He wrote back and said, "You want to study with Dr. Marjorie Shaw, professor of genetics at the University of Texas in Houston." She was going to law school at the time!

Upon graduation from law school, I enrolled in a $\mathrm{PhD}$ course in human genetics. After 2 years, I decided that I was better suited to be a clinical geneticist than a bench scientist. I was more interested in human disease than in bacterial genetics. I left the program and went to work as a lawyer for one year in health law. There was a program at Yale Law School in law, science, and medicine. I applied. From that position I applied to Yale Medical School in New Haven, CT. I [became] a straight medical student.

I went to do a residency in internal medicine. You did not do a residency in genetics in those days. You got your training in clinical genetics in sort of an ad hoc fashion. I spent a year after my internship as essentially a professor of law. I felt that the ultimate definition of privacy would be knowledge about your genes. I thought that genetics was going to change forensics and would be of interest to family law, the insanity defense, insurance, and employment.

I'm glad I went to law school, but my heart is really with genetics. My father was a doctor. I was exposed to the world of medicine, the suffering. I was very interested in the notion of causality. I don't want to sound like a determinist, but the notion that DNA can be the ultimate source of information about life appealed to me in a very aesthetic sense.

I took a job at the Shriver Center for Mental Retardation in
Waltham, MA. I wound up director of the medical program that oversaw the care of 700 institutionalized retarded people, many of whom had poorly described genetic disorders. I would not describe myself as a basic scientist. I would describe myself as someone very interested in the translation of scientific knowledge into health care and the world at large. I have never made a fundamental contribution to knowledge. I've made my contributions in translating knowledge for other people.

At the Shriver Center, one of the frustrations was a genetic form of retardation called fragile $\mathrm{X}$ syndrome. It's about as common as Down syndrome. Everybody knows Down syndrome. To this day, most people don't know fragile $\mathrm{X}$. The earlier you have the diagnosis, the earlier you can make proper interventions. Every time a child came in with unexplained mental retardation, I would argue with the neurologists. I would say, "You've got to screen for fragile X." It was two or three years of battling with the neurologists to get them to accept the notion of genetic testing.

I was also very interested in science policy and did a lot of advisory work, mostly about genetics and public policy. I had a growing number of contacts as a consultant in what became the genome industry, usually in the role of a kind of bioethics advisor. [People] would approach me about taking jobs.

I want two things to be written on my epitaph. One is that he was a good dad and two is that he helped move genetics into medicine. I thought, "Though new knowledge is generated in academe, it's applied in industry. Put your commitment where your mouth is and see if you can help bring genetic information into the larger society." In my work as CEO of Interleukin Genetics, we're trying to develop new genetic tests that are not focused on disease risk but on health promotion. That's the core thesis of my life. Let's find out what [the genetics is] and intervene to avoid disease.

As told to Beryl Lieff Benderly, a health and science writer in Washington, DC. 